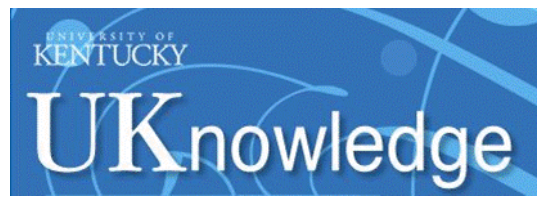

University of Kentucky

UKnowledge

Toxicology and Cancer Biology Faculty

Publications

Toxicology and Cancer Biology

$2-2014$

\title{
Ether Bridge Formation in Loline Alkaloid Biosynthesis
}

\author{
Juan Pan \\ University of Kentucky, juan.pan@uky.edu \\ Minakshi Bhardwaj \\ University of Kentucky, minakshi.bhardwaj@uky.edu \\ Jerome Ralph Faulkner \\ University of Kentucky, jfaulkner1@gmail.com \\ Padmaja Nagabhyru \\ University of Kentucky, padmaja.nagabhyru@uky.edu \\ Nikki D. Charlton \\ The Samuel Roberts Noble Foundation
}

See next page for additional authors

Follow this and additional works at: https://uknowledge.uky.edu/toxicology_facpub

Part of the Medical Toxicology Commons

Right click to open a feedback form in a new tab to let us know how this document benefits you.

\section{Repository Citation}

Pan, Juan; Bhardwaj, Minakshi; Faulkner, Jerome Ralph; Nagabhyru, Padmaja; Charlton, Nikki D.; Higashi, Richard M.; Miller, Anne-Frances; Young, Carolyn A; Grossman, Robert B.; and Schardl, Christopher L., "Ether Bridge Formation in Loline Alkaloid Biosynthesis" (2014). Toxicology and Cancer Biology Faculty Publications. 43.

https://uknowledge.uky.edu/toxicology_facpub/43

This Article is brought to you for free and open access by the Toxicology and Cancer Biology at UKnowledge. It has been accepted for inclusion in Toxicology and Cancer Biology Faculty Publications by an authorized administrator of UKnowledge. For more information, please contact UKnowledge@lsv.uky.edu. 


\section{Ether Bridge Formation in Loline Alkaloid Biosynthesis}

\section{Digital Object Identifier (DOI)}

http://dx.doi.org/10.1016/j.phytochem.2013.11.015

\section{Notes/Citation Information}

Published in Phytochemistry, v. 98, p. 60-68.

Copyright @ 2013 Elsevier Ltd. All rights reserved.

This manuscript version is made available under the CC-BY-NC-ND 4.0 license

http://creativecommons.org/licenses/by-nc-nd/4.0/

\section{Authors}

Juan Pan, Minakshi Bhardwaj, Jerome Ralph Faulkner, Padmaja Nagabhyru, Nikki D. Charlton, Richard M. Higashi, Anne-Frances Miller, Carolyn A Young, Robert B. Grossman, and Christopher L. Schardl 


\section{Copyright (C) 2013 Elsevier Ltd. All rights reserved.}

This manuscript version is made available under the CC-BY-NC-ND 4.0 license http://creativecommons.org/licenses/by -nc-nd $/ 4.0 /$ 
Published in final edited form as:

Phytochemistry. 2014 February ; 98: 60-68. doi:10.1016/j.phytochem.2013.11.015.

\title{
Ether bridge formation in loline alkaloid biosynthesis
}

\author{
Juan Pan ${ }^{\mathrm{a}}$, Minakshi Bhardwaj ${ }^{\mathrm{b}}$, Jerome R. Faulkner ${ }^{\mathrm{a}, 1}$, Padmaja Nagabhyru ${ }^{\mathrm{a}}$, Nikki D. \\ Charlton $^{\mathrm{c}}$, Richard M. Higashid ${ }^{\mathrm{d}}$, Anne-Frances Miller ${ }^{\mathrm{b}}$, Carolyn A. Young ${ }^{\mathrm{c}}$, Robert B. \\ Grossman $^{\mathrm{b}}$, and Christopher L. Schardla, ${ }^{*}$ \\ aDepartment of Plant Pathology, University of Kentucky, Lexington, KY 40546 \\ ${ }^{b}$ Department of Chemistry, Chemistry-Physics Building, University of Kentucky, Lexington, KY \\ 40506
}

'The Samuel Roberts Noble Foundation, Ardmore, OK 73401

${ }^{\mathrm{d}}$ Graduate Center for Toxicology, 521 Biopharmacy Building, Lexington KY 40536

\begin{abstract}
Lolines are potent insecticidal agents produced by endophytic fungi of cool-season grasses. These alkaloids are composed of a pyrrolizidine ring system and an uncommon ether bridge linking carbons 2 and 7. Previous results indicated that 1-aminopyrrolizidine was a pathway intermediate. We used RNA interference to knock down expression of $l o l O$, resulting in the accumulation of a novel alkaloid identified as exo-1-acetamidopyrrolizidine based on high-resolution MS and NMR. Genomes of endophytes differing in alkaloid profiles were sequenced, revealing that those with mutated $l o l O$ accumulated exo-1-acetamidopyrrolizidine but no lolines. Heterologous expression of wild-type $l o l O$ complemented a lolO mutant, resulting in the production of $\mathrm{N}$-acetylnorloline. These results indicated that the non-heme iron oxygenase, LolO, is required for ether bridge formation, probably through oxidation of exo-1-acetamidopyrrolizidine.
\end{abstract}

\section{Keywords}

Epichloë spp.; Clavicipitaceae; grass symbionts; genome sequencing; pyrrolizidines; loline alkaloids; exo-1-acetamidopyrrolizidine; oxoglutarate/iron-dependent dioxygenase; lolO

\section{Introduction}

The Epichloë species are fungi in the family Clavicipitaceae that grow as symbionts of coolseason grasses (Poaceae, subfamily Pooideae). Often Epichloë species confer to their hosts a range of fitness benefits, including enhanced resistance to biotic and abiotic stresses (Schardl et al., 2004). One such benefit is defense against plant herbivores that is attributable to the various alkaloids produced by these fungi. For example, tall fescue (Lolium arundinaceum (Schreb.) Darbysh.) cv. Kentucky 31 infected with Epichloë coenophiala C.W. Bacon \& Schardl (Morgan-Jones et W. Gams) [=Neotyphodium coenophialum (Morgan-Jones et W. Gams) Glenn, C.W. Bacon \& Hanlin] possesses three classes of

\footnotetext{
(C) 2013 Elsevier Ltd. All rights reserved.

Corresponding author: *Christopher L. Schardl; Telephone: 1-859-218-0730; Fax: 1-859-323-1961; schardl@uky.edu. ${ }^{1}$ Present address: Kentucky NRCS State Office, 771 Corporate Drive, Suite 210, Lexington, KY 40503

Publisher's Disclaimer: This is a PDF file of an unedited manuscript that has been accepted for publication. As a service to our customers we are providing this early version of the manuscript. The manuscript will undergo copyediting, typesetting, and review of the resulting proof before it is published in its final citable form. Please note that during the production process errors may be discovered which could affect the content, and all legal disclaimers that apply to the journal pertain.
} 
protective alkaloids: ergot alkaloids, peramine, and lolines. Ergot alkaloids from this grass are notorious for causing fescue toxicosis to livestock, resulting in hundreds of millions of dollars in annual losses to the U.S. cattle industry (Hoveland, 1993; Schardl, 2006). Loline alkaloids, also produced by the symbionts of other forage grasses such as Italian ryegrass (Lolium multiflorum Lam.) and meadow fescue (Lolium pratense (Huds.) Darbysh.), as well as many wild grasses (Schardl et al., 2012), appear to have no adverse effects on livestock and vertebrate wildlife (Schardl et al., 2007). However, lolines are potently active against a broad spectrum of insect species (Bultman et al., 2004; Wilkinson et al., 2000; Yates et al., 1989) and may also help protect against nematodes (Bacetty et al., 2009). This spectrum of biological activity makes the lolines particularly attractive for Epichloë species that could provide bioprotection to forage grasses and thereby contribute to sustainable agriculture.

The lolines (Fig. 1) are saturated exo-1-aminopyrrolizidines with an oxygen bridge between carbons 2 (C2) and 7 (C7), causing the pyrrolizidine ring to be strained. Such an ether linkage is a characteristic rarely found in natural metabolites. Through isotopic enrichment experiments, we have identified L-proline (Pro) and L-homoserine as precursors in a lolineforming biosynthetic pathway that proceeds via $N$-(3-amino-3-carboxypropyl)proline and exo-1-aminopyrrolizidine (1a) (Blankenship et al., 2005; Faulkner et al., 2006). These findings indicate that the ether bridge forms after the completion of the pyrrolizidine ring system, which, in turn, excludes many common routes of ether formation in natural products, such as reduction of acetals or hemiacetals (Dominguez de Maria et al., 2010).

In several Epichlö̈ species, a gene cluster, designated $L O L$, has been identified with up to 11 genes, in the sequence lolF, lolC, lolD, lolO, lolA, lolU, lolP, lolT, lolE, lolN, and lolM, and is strictly associated with the biosynthesis of lolines (Kutil et al., 2007; Schardl et al., 2013; Spiering et al., 2005). The predicted products of $L O L$ genes include three pyridoxalphosphate (PLP)-containing enzymes (LolC, LolD, and LolT) and four enzymes involved in oxidation/oxygenation reactions (LolF, LolO, LolP, and LolE). Among the potential oxidizing enzymes, LolP has been functionally characterized previously to catalyze the oxidation of $\mathrm{N}$-methylloline (7) to $\mathrm{N}$-formylloline (8) (one of the most abundant loline alkaloids found in grasses) and is not required for earlier steps (Spiering et al., 2008). LolF is likely to be involved in pyrrolizidine formation (Schardl et al., 2007), and, as an FADcontaining monooxygenase, it probably would not provide the oxidative potential for formation of the ether bridge. Hence LolO and LolE, predicted to be non-heme iron aketoacid-dependent dioxygenases, are the most likely candidate enzymes for catalyzing ether bridge formation. Here, we demonstrate that $\mathrm{LolO}$ is required to form the ether bridge, and we identify a new pathway intermediate, exo-1-acetamidopyrrolizidine (2a) (Fig. 1a), and hypothesize it to be the direct biosynthetic precursor of the loline alkaloids.

\section{Results}

\subsection{Identification of exo-1-acetamidopyrrolizidine (2a)}

Expression of the lolO RNAi construct in transformed Epichloë uncinata (W. Gams, Petrini \& D. Schmidt) Leuchtm. \& Schardl [=Neotyphodium uncinatum (W. Gams, Petrini \& D. Schmidt) Glenn, C.W. Bacon \& Hanlin] altered the loline alkaloid profile, giving a major peak of a previously unknown compound with a 12.0 min retention time in the gas chromatogram (Fig. 2). Although the same peak was also observed in the vector-only and wild-type controls, the area of this peak relative to 8 and $N$-acetylnorloline (5) was much greater in extracts from the RNAi strain cultures compared to the controls. The mass spectrum of the compound had no match when searched against the organic spectral database at http://riodb01.ibase.aist.go.jp/sdbs/cgi-bin/direct_frame_top.cgi. Fourier transform ion cyclotron resonance mass spectrometry (FTICR-MS) determined the mass to be $169.13355 \mathrm{amu}$, which is within $0.059 \mathrm{ppm}$ of the theoretical mass of protonated 1- 
acetamidopyrrolizidine (2), an aminopyrrolizidine alkaloid related to the lolines, but lacking the ether bridge (Fig. 1). The newly discovered alkaloid $\mathbf{2}$ was also identified as the only loline-related metabolite produced in Brachyelytrum erectum (Schreb.) P.Beauv. symbiotic with Epichloë brachyelytri Schardl \& Leuchtm. strain E4804, and in Elymus canadensis L. plant 4814, symbiotic with a strain (designated e4814) of Epichloë canadensis N.D. Charlton \& C.A. Young.

In order to determine the relative configuration ( $\mathbf{2} \mathbf{a}$ or $\mathbf{2 b}$ ) with certainty, compound $\mathbf{2}$ was purified from tillers collected from plant 4814 and compared to synthetic ( \pm )-exo-1acetamidopyrrolizidine $(( \pm)-\mathbf{2 a})$. We initiated the synthesis of $\mathbf{2 a}$ (Fig. 3) by reducing $( \pm)-1$ oximinopyrrolizidine with Raney nickel in tetrahydrofuran (THF) until starting material had been consumed. At this point, we observed one major and one minor spot by TLC, consistent with the formation of diastereomers $( \pm)-\mathbf{1 a}$ and $( \pm)-\mathbf{1 b}$, respectively, as previously reported for the reduction of the oxime in isopropanol (Christine et al., 2000; Faulkner et al., 2006). We then added $\mathrm{Ac}_{2} \mathrm{O}$ and 4-dimethylaminopyridine (DMAP) to the reaction mixture. After $2 \mathrm{~h}$, the minor diastereomer of $\mathbf{1}$ remained unchanged, but the major diastereomer was replaced by a product that we identified as $\mathbf{2}$. The reaction did not proceed further after overnight stirring. Because only the major diastereomer of $\mathbf{1}$, which should be 1a, reacted with $\mathrm{Ac}_{2} \mathrm{O}$ to give $\mathbf{2}$, we concluded that the relative configuration of the new compound to be exo, or $\mathbf{2 a}$.

\subsection{Accumulation of compound $2 \mathrm{a}$ is associated with $\mathrm{lolO}$ mutations}

Different loline alkaloid profiles were found to be associated with grasses symbiotic with various fungi including strains of Epichloë amarillans J.F. White in Agrostis hyemalis (Walter) Britton, Sterns \& Poggenb., E. amarillans in Sphenopholis obtusata (Michx.) Scribn., Epichloë festucae Leuchtm. Schardl et M.R. Siegel in L. pratense, and the related fungus, Atkinsonella hypoxylon (Pk.) Diehl, in Danthonia spicata (L.) P.Beauv. ex Roem. \& Schult. Three distinct loline profiles were observed. Plants with E. festucae E2368, like plants with E. uncinata e167 and E. coenophiala e19, accumulated loline (3), 5, Nacetylloline (6), 7, and 8. Plants with E. amarillans E57 and E. canadensis e 4815 had 5, but no other fully-cyclized lolines, and plants with E. amarillans strains E721, E722 and E862, E. brachyelytri $\mathrm{E} 4804$, E. canadensis $\mathrm{e} 4814$, and A. hypoxylon $\mathrm{B} 4728$ had 2, but none of the lolines.

Genomes of several symbionts were sequenced to identify and characterize all $L O L$-cluster genes in each (Fig. 4). Strains from plants with 2a, but without lolines, had mutated $l o l O$ but apparently functional genes lolF, lolC, lolD, lolA, lolU, lolT and lolE in the LOL clusters. The genome sequences, as well as sequences of PCR products from additional strains, revealed that each strain that produced several lolines or only $\mathbf{5}$ had intact lolO genes, whereas those producing only $2 \mathrm{a}$ all had mutant $l o l O$ genes (Fig. 5). For example, the lolO gene of E. brachyelytri $\mathrm{E} 4804$ had a frame-shift mutation in the first exon and a deletion that extended into the second exon. Likewise, in A. hypoxylon $\mathrm{B} 4728$, lolO had a large deletion extending through the first exon and part of the second, and a frame-shift mutation in the second exon. The observation that defective $l o l O$ genes in four strains differed in positions of insertions and deletions implied independent origins of $l o l O$-inactivating mutations associated with the accumulation of $\mathbf{2 a}$ and absence of lolines.

\subsection{Heterologous expression of wild-type $10 / O$ complemented a natural $I 0 / O$ mutant}

A genetic complementation experiment was conducted to test the hypothesis that $l o l O$ mutations caused the loline alkaloid pathway to terminate at 2a. Epichloë canadensis e4814, possessing a mutated $l o l O$, was transformed with pKAES309, which contains wild-type lolO with its own promoter cloned from E. festucae E2368. Three independent transformants 
were obtained and introduced back into endophyte-free El. canadensis plants. Expression of lolO in symbio was checked by RT-PCR with primers targeting the region that included the deletion in e4814. Sequences of the RT-PCR products indicated that the pKAES309 transformants transcribed both the endogenous mutated $l o l O$ and the introduced wild-type $l o l O$, whereas only the mutated $l o l O$ was transcribed in the wild-type and vector-only controls. Furthermore, plants inoculated with pKAES309 transformants showed accumulation of both $\mathbf{2 a}$ and $\mathbf{5}$ (Fig. 6), supporting the hypothesized role of LolO.

\subsection{Labeling from $\mathrm{L}-\left[\mathrm{U}-{ }^{2} \mathrm{H}_{7}\right]$ Pro showed retention of the deuterium atoms in lolines}

In order to determine if exchange of hydrogen on the Pro-derived ring occurs during loline alkaloid biosynthesis, $\mathrm{L}-\left[\mathrm{U}_{-}{ }^{2} \mathrm{H}_{7}\right]$ Pro was applied to El. canadensis plant 4814. Loline alkaloids were extracted and analyzed by GC-MS. Heptadeuterated 2a was observed at the front edge of the GC peak of 2a (Fig. 7). A $+7 \mathrm{~m} / \mathrm{z}$ enrichment was observed in the parent ion $(m / z=169$ to 176$)$, and in the major fragment ion, which contains the Pro-derived ring $(\mathrm{m} / \mathrm{z}=83$ to 90$)$. Similarly, $\mathrm{L}-\left[\mathrm{U}-{ }^{2} \mathrm{H}_{7}\right]$ Pro was applied to $E$. uncinata e167 cultures, and loline alkaloids were analyzed by GC-MS. Extracts from the treated culture (Fig. 8), but not from culture lacking labeled Pro (not shown), gave a GC peak adjacent to the peak corresponding to $\mathbf{8}$. This novel peak was determined by MS to contain mainly hexadeuterated 8. A $+6 \mathrm{~m} / z$ enrichment was observed in the parent ion $(\mathrm{m} / z=183$ to 189$)$, its likely deformylated derivative $(\mathrm{m} / z=153$ to 159$)$, the major fragment ion $(\mathrm{m} / \mathrm{z}=82$ to 88), and other fragment ions predicted to contain all carbon atoms from the proline ring (Schardl et al., 2007). These results imply that the loline alkaloid biosynthetic pathway, including ether bridge formation, never involves desaturation or epoxide formation of the Pro-derived ring.

\section{Discussion}

Loline alkaloids produced by endophytic fungi protect host grasses by affecting a large range of insects, so elucidation of their biosynthetic pathway aids the application of lolines in insect control in forage grasses. Our evidence supports the hypothesis that LolO is required for ether bridge formation in the biosynthesis of loline alkaloids. The lack of a functional $l o l O$ gene consistently correlated with accumulation of 2a and the apparent absence of any loline alkaloids. Independent mutations in $l o l O$ were evident in $E$. brachyelytri $\mathrm{E} 4804$, E. canadensis $\mathrm{e} 4814$, E. amarillans $\mathrm{E} 722$, E721 and E862, and A. hypoxylon B4728, all of which accumulated 2a. In the lolO RNAi experiment, 2a consistently accumulated to high levels relative to the lolines. Furthermore, a copy of wildtype lolO complemented the natural $l o l O$ mutation in e4814, giving substantial levels of $\mathbf{5}$. All of these findings indicate that LolO, and possibly additional enzymes (discussed later), catalyze ether formation.

Lolines have an unusual ether linkage of two bridgehead carbons. Previous finding that 1a forms prior to the ether bridge (Faulkner et al., 2006), along with the current observation that six deuterium atoms from $\mathrm{L}-\left[\mathrm{U}_{-}{ }^{2} \mathrm{H}_{7}\right]$ Pro are retained in lolines, eliminates several possible mechanisms commonly responsible for biological ether formation, including addition to double bonds and opening of epoxides (Dominguez de Maria et al., 2010), suggesting an unusual mechanism for loline ether formation.

We propose a possible mechanism of ether bridge formation in lolines, involving hydroxylation of one of the bridgehead carbons, abstraction of a hydrogen atom from the other, and ether bridge closure (Fig. 9), although other mechanisms are possible. Of the other three oxidative enzymes encoded in the $L O L$ cluster, a gene knockout demonstrated that LolP is not required for this step (Spiering et al. 2009), results of a similar test suggest that LolE may not be required (J.P., unpublished data), and LolF, which is predicted to be an 
FAD-containing monooxygenase, probably does not provide sufficient oxidative potential to catalyze oxidation at $\mathrm{C} 2$ or $\mathrm{C} 7$. A possible function of LolF is oxidative decarboxylation of the proline-derived ring to give an iminium ion intermediate (Faulkner et al., 2006; Zhang et al., 2009), but so far we cannot rule out the possibility of its involvement in conjunction with LolO. Alternatively, LolO could be the only enzyme required to form the ether linkage. An example of a single enzyme that catalyzes several oxidizing steps in a pathway is clavaminic acid synthase, which is also involved in generating an ether linkage (Zhang et al., 2000).

Since lolO RNAi and lolO mutant strains all showed accumulation of 2a, it is likely that $\mathbf{2 a}$ is the first substrate for the series of steps involved in ether bridge formation, and that LolO catalyzes at least the first step. The $L O L$ gene clusters of strains that produce 5 (E57 and e4815), and those that accumulate 2a (e4814, E722, E4804, and B4728), have the same complement of potentially functional genes in the $L O L$ cluster, with the exception of the mutated $l o l O$ genes in the latter. Hence, it is reasonable to hypothesize that 2a is the intermediate that is converted to the first loline alkaloid, $\mathbf{5}$. Considering the previous evidence that 1a is a pathway intermediate, it is predicted that 2a is generated by acetylation of 1a (Fig. 10).

Based on the observation that the lolines $\mathbf{3}, \mathbf{4}, \mathbf{5}, \mathbf{7}$, and $\mathbf{8}$ are found in many grasses, and the predicted functions of $L O L$ genes in the cluster, we hypothesize that, after formation of 2a, the loline biosynthetic pathway proceeds through deacetylation of $\mathbf{5}$ to form $\mathbf{4}$ by LolN, the predicted acetamidase (Fig. 10). Serial methylations of $\mathbf{4}$ by LolM, the predicted methyltransferase, then produce $\mathbf{3}$ and $\mathbf{7}$, the latter of which is oxidized to $\mathbf{8}$ by the cytochrome P450 enzyme, LolP (Spiering et al., 2008). We are also considering an alternative but more complex hypothesis, namely, that $1 \mathbf{a}$ is the actual substrate on which the ether is formed, whereas $\mathbf{2 a}$ is a side product. If that were the case, the likely role of LolN would be to deacetylate 1a to 2a, and $\mathbf{4}$ would be the first loline (Fig. 10). However, in this alternative pathway, LolN would appear to be either unnecessary or involved in a futile cycle between $\mathbf{4}$ and $\mathbf{5}$. Hence, it is more plausible that 2a is the actual intermediate in loline biosynthesis that is oxidized to $\mathbf{5}$. We plan further experiments to test this hypothesis.

Neither alkaloid $\mathbf{2 a}$ nor $\mathbf{2 b}$ has been previously reported. We were unable to establish the relative configuration (exo, $\mathbf{2 a}$, or endo, $\mathbf{2 b}$ ) of isolated $\mathbf{2}$ by analysis of its NOESY spectrum, so we prepared synthetic ( \pm )-2a as a comparison material. The NMR spectra $\left({ }^{1} \mathrm{H},{ }^{13} \mathrm{C}, \mathrm{COSY}, \mathrm{NOESY}\right.$, and HSQC) and GC-MS of the synthetic $( \pm)-\mathbf{2 a}$ and the isolated 2 were very similar, and the GC and the ${ }^{1} \mathrm{H}$ and ${ }^{13} \mathrm{C}$ NMR spectra of an equimolar mixture of synthetic and isolated material (Supplementary data) showed only a single compound, establishing with high confidence that the isolated alkaloid was also 2a. This assignment was consistent with both the known configuration of the loline alkaloids and our previous work showing that 1a was an intermediate in the biosynthetic pathway of lolines (Faulkner et al., 2006).

The lolines are comparable to nicotine in insecticidal activity (Riedell et al., 1991), so they are probably a major factor in the protective effects of certain endophytes. For example, the loline-producing endophytes, Epichloë occultans (C.D. Moon, B. Scott \& M.J. Chr.) Schardl in L. multiflorum and E. coenophiala in tall fescue, have documented activity on herbivorous insects as well as their parasitoids, playing an important role in arthropod diversity and food-web structures (Omacini et al., 2001; Rudgers and Clay, 2008). Notably, different lolines vary in specificity and impact on different insects (Jensen et al., 2009; Popay et al., 2009; Riedell et al., 1991). Considering that 2a is the pathway end-product that originated independently in several natural species of grass endophytes, it is possible that this alkaloid is specifically selected in some environments, perhaps by variation of the dominant herbivore species. Hence, the biological activity of $\mathbf{2 a}$ merits further study. 


\section{Concluding Remarks}

Through genome sequencing and molecular genetic methods, LolO, a non-heme iron oxygenase, was revealed to be required for loline ether bridge formation. The mechanism of the reaction is not yet determined, but the finding that six deuterium atoms from L$\left[\mathrm{U}^{2} \mathrm{H}_{7}\right]$ Pro were retained in $\mathbf{8}$, together with the finding that the pyrrolizidine rings form before the ether bridge, ruled out several possible common mechanisms, such as epoxide formation and opening. Hence, it is likely that formation of the ether bridge of lolines occurs through an unusual route, possibly through a free radical at $\mathrm{C} 2$ or C7. A novel natural product described here, exo-1-acetamidopyrrolizidine (2a), is a likely pathway intermediate that is oxidized at $\mathrm{C} 2$ and $\mathrm{C} 7$ to form the ether bridge, giving rise to $\mathbf{5}$, the first loline alkaloid in the pathway.

\section{Experimental}

\subsection{General experimental procedures}

GC-MS was conducted using a Varian CP-3800 GC (Agilent Technologies, Santa Clara, CA, USA) and a Varian Saturn 2200 MS (Agilent Technologies). The GC was equipped with an Agilent J\&W DB-5MS capillary column ( $30 \mathrm{~m}, 0.25 \mathrm{~mm}$ i.d., 0.25 um thickness). Helium at $1 \mathrm{ml} / \mathrm{min}$ was used as the carrier gas with an injection temperature of $250{ }^{\circ} \mathrm{C}$. Column temperature was initially $75^{\circ} \mathrm{C}$, increased to $225^{\circ} \mathrm{C}$ at $8{ }^{\circ} \mathrm{C} / \mathrm{min}$, then increased to $300{ }^{\circ} \mathrm{C}$ at $25^{\circ} \mathrm{C} / \mathrm{min}$, and held for $5 \mathrm{~min}$ for a total run time of $27 \mathrm{~min}$. For GC-MS detection, an electron ionization system was used with ionization energy of $70 \mathrm{eV}$. Mass range was set at $50-250 \mathrm{~m} / \mathrm{z}$ with a filament delay of $4 \mathrm{~min}$.

Fourier transform ion cyclotron resonance (FTICR) mass spectrometry was performed using a Thermo Electron LTQ-FT with Advion Nanomate nanoelectrospray source operating in the positive ion mode. Fragmentation in the ICR cell used infrared multi-photon dissociation (IRMPD) with $80 \mathrm{msec}$ pulse following a $2 \mathrm{msec}$ delay. Spectra were acquired using a resolving power of 100,000 @ $400 \mathrm{~m} / z$, resulting in resolution of much better than 1 ppm across the measured $\mathrm{m} / \mathrm{z}$ range. The instrument was externally calibrated to protonated reserpine.

DNA cloning was carried out by standard methods, and plasmids were grown in Escherichia coli XL1-Blue (Agilent Technologies). All plasmid DNA was isolated from bacterial cultures (LB medium at $37{ }^{\circ} \mathrm{C}$ for $20 \mathrm{~h}$ on a rotary shaker at $200 \mathrm{rpm}$ ) with ZR Plasmid Miniprep-Classic kit (Zymo Research, Irvine, CA, USA) according to the manufacturer's protocol. Fungal genomic DNA was isolated with ZR Fungal/Bacterial DNA MiniPrep (Zymo Research) following the manufacturer's instructions. Gene screenings by polymerase chain reaction (PCR) were conducted with AmpliTaq Gold (Applied Biosystems, Foster City, CA, USA) in manufacturer- provided PCR buffer with $1.5 \mathrm{mM} \mathrm{MgCl}_{2}$. For gene cloning, PCR was performed with Phusion Hot Start High-Fidelity DNA Polymerase (Thermo Scientific, Ratastie, Vantaa, Finland) with provided HF buffer with $1.5 \mathrm{mM}$ $\mathrm{MgCl}_{2}$. All oligonucleotide primers were ordered from Integrated DNA Technologies (Coralville, Iowa, USA), and are listed in Table 1.

\subsection{Biological materials}

Fungal isolates were cultured from infected plants as previously described (Blankenship et al., 2001), and are listed in Table 2. The strain designations refer to the plant numbers from which they were isolated, with prefix of "E" and "e" for sexual and asexual Epichlö̈ species, respectively, and "B" for Atkinsonella hypoxylon (Balansia hypoxylon Diehl). 


\subsection{Loline alkaloid analysis}

Grass materials used in this study were all clipped from the crown, lyophilized and ground. For GC-MS analysis, ground plant material $(100 \mathrm{mg})$ was extracted with $\mathrm{NaOH}(100 \mu \mathrm{l}, 1$ $\mathrm{M})$ and loline-alkaloid extraction solution (1 $\mathrm{ml}, 99 \%$ chloroform with $1 \%$ quinoline as internal standard). The mixture was agitated for $1 \mathrm{~h}$ at room temperature, then centrifuged at $16 \times 10^{3} \mathrm{~g}$ for 10 to $15 \mathrm{~min}$. The organic phase was transferred to a capped glass vial for GC-MS analysis as previously described (Faulkner et al., 2006).

Loline alkaloid production by E. uncinata 167 and the transformed strains was induced in minimum medium (MM) as described in (Blankenship et al., 2001; Chung and Schardl, 1997), with $15 \mathrm{mM}$ urea as the nitrogen source and $20 \mathrm{mM}$ sucrose as the carbon source. For isotopic labeling, $4 \mathrm{mM} \mathrm{L}-\left[\mathrm{U}_{-}{ }^{2} \mathrm{H}_{7}\right]$ Pro was included in the medium. Fungal isolates were ground in sterile water and inoculated to $30 \mathrm{ml}$ of $\mathrm{MM}$ in $100 \times 25 \mathrm{~mm}$ polystyrene Petri dishes. After 13-20 days shaking at $21{ }^{\circ} \mathrm{C}$, the medium was sampled for loline alkaloids analysis by GC-MS, as previously described (Blankenship et al., 2005).

\subsection{Plasmid construction}

For lolO RNAi, a 200 bp fragment was amplified from E. uncinata e167 using primers lolOrnaiF1 and lolOrnaiR $1\left(95^{\circ} \mathrm{C}\right.$ for $5 \mathrm{~min}, 35$ cycles of $95^{\circ} \mathrm{C}$ for $30 \mathrm{~s}, 61^{\circ} \mathrm{C}$ for $30 \mathrm{~s}$, and $72{ }^{\circ} \mathrm{C}$ for $1 \mathrm{~min}$ ). The PCR product was purified and digested with $E c o \mathrm{RV}$ and $\mathrm{Xba \textrm {I }}$, for which sites were incorporated into the primers. Similarly, a $280 \mathrm{bp}$ fragment of $l o l O$ was amplified from $E$. uncinata e167 by PCR with primers lolOrnaiF2 and lolOrnaiR2 $\left(95^{\circ} \mathrm{C}\right.$ for $5 \mathrm{~min}, 35$ cycles of $95^{\circ} \mathrm{C}$ for $30 \mathrm{~s}, 6{ }^{\circ} \mathrm{C}$ for $30 \mathrm{~s}$, and $72{ }^{\circ} \mathrm{C}$ for $1 \mathrm{~min}$ ), purified and digested with SpeI and XbaI. Plasmid pKAES215 was digested with SpeI and EcoRV. The $4.8 \mathrm{~kb}$ fragments of the digested plasmid and digested PCR products were gel purified by QIAquick Gel Extraction Kit (Qiagen, Valencia, CA, USA). The three fragments of sizes $0.2 \mathrm{~kb}, 0.28 \mathrm{~kb}$, and $4.8 \mathrm{~kb}$ were mixed in a molar ration of 2:2:1 and ligated using the FastLink DNA ligation kit (Epicentre, Madison, WI, USA). The resulting plasmid, designated pKAES226, contained the TOXA promoter from Pyrenophora tritici-repentis (Died.) Drechsler (Andrie et al., 2005) driving the first exon and intron of $l o l O$, followed by the reverse complement of the first exon of lolO.

For $l o l O$ complementation, a DNA segment including $l o l O$ and the entire flanking intergenic regions was amplified from DNA of E. festucae E2368, by PCR with primers lolAkoupf and lolAkoupr $\left(98{ }^{\circ} \mathrm{C}\right.$ for $5 \mathrm{~min}, 35$ cycles of $98{ }^{\circ} \mathrm{C}$ for $30 \mathrm{~s}, 57{ }^{\circ} \mathrm{C}$ for $30 \mathrm{~s}$, and $72{ }^{\circ} \mathrm{C}$ for 2 $\mathrm{min})$. The PCR product was purified and digested with $\mathrm{XbaI}$, the site for which was incorporated in the primer lolAkoupr. Plasmid pKAES215 was digested with XbaI and SmaI. The two fragments were then gel purified and ligated to produce plasmid pKAES309, which has $l o l O$ of E. festucae E2368 under its own promoter.

\subsection{Fungal transformation}

Epichloë canadensis e 4814 was grown in potato dextrose broth $(50 \mathrm{ml})$ for 5 days at $22{ }^{\circ} \mathrm{C}$ with rotary shaking $(200 \mathrm{rpm})$. Fungal mycelium was harvested by centrifugation at $4885 \mathrm{~g}$, resuspended in $3.75 \mathrm{mg} / \mathrm{ml}$ vinoflow (Novozymes, Bagsvaerd, Denmark), $5 \mathrm{mg} / \mathrm{ml}$ driselase (InterSpex products, San Mateo, CA), $0.7 \mathrm{mg} / \mathrm{ml}$ zymicase I (InterSpex Products), $5 \mathrm{mg} / \mathrm{ml}$ lysing enzymes (Sigma, St. Louis, MO), and $2.5 \mathrm{mg} / \mathrm{ml}$ bovine serum albumin (Sigma) in osmotic solution (1.2 $\mathrm{M} \mathrm{MgSO}_{4}, 50 \mathrm{mM}$ sodium citrate, $\left.\mathrm{pH} 6.0\right)$, and gently agitated $3 \mathrm{~h}$ at $30{ }^{\circ} \mathrm{C}$. Protoplast isolation and electroporation were performed as described by (Tsai et al., 1992).

After electroporation, the protoplasts were mixed with regeneration medium $(5 \mathrm{ml})$ (Panaccione et al., 2001) and plated onto potato dextrose agar (PDA) $(20 \mathrm{ml})$ with $125 \mu \mathrm{g} /$ 
$\mathrm{ml}$ hygromycin $\mathrm{B}$, so the final concentration of hygromycin B over the whole plate $(25 \mathrm{ml})$ was $100 \mu \mathrm{g} / \mathrm{ml}$. Plates were kept at $22{ }^{\circ} \mathrm{C}$ and checked after ca. 2 wk. Fungal colonies were transferred to PDA plates with $100 \mu \mathrm{g} / \mathrm{ml}$ hygromycin B and then single-spore isolated two times before further analysis. Transformants were introduced into host plants by the method of Latch and Christensen (1985), by inoculation of seedlings from endophyte-free seed lots. When the plants had at least three tillers, a tiller from each was sacrificed for tissue-print immunoblot as previously described (An et al., 1993).

\subsection{Purification of exo-1-acetamidopyrrolizidine (2a)}

Approximately $10 \mathrm{~g}$ lyophilized El. canadensis plant 4814 tillers were used to extract 2a with the loline extraction method described in part 5.3. The extract was chromatographed twice on $1 \mathrm{~mm}$ thick silica gel prep. TLC plates (EMD Chemicals, Darmstadt, Germany) (Blankenship et al., 2005). Purified 2a was recovered in deuterated chloroform and analyzed by NMR. Compound 2a was named $N$-[( $1 S, 7 \mathrm{a} R)$-hexahydro- $1 H$-pyrrolizin-1-yl $]$ acetamide according to IUPAC nomenclature and was given the common name, exo-1acetamidopyrrolizidine. Purified 2a showed ${ }^{1} \mathrm{H}$ NMR $\left(600 \mathrm{MHz}, \mathrm{CDCl}_{3}, 0.10 \mathrm{M}\right): \delta 1.59$ $\left(\mathrm{dq}, J_{\mathrm{d}}=12.6 \mathrm{~Hz}, J_{\mathrm{q}}=7.4 \mathrm{~Hz}, 1 \mathrm{H}\right), 1.72\left(\mathrm{dq}, J_{\mathrm{d}}=13.8 \mathrm{~Hz}, J_{\mathrm{q}}=7.1 \mathrm{~Hz}, 1 \mathrm{H}\right), 1.73\left(\mathrm{dq}, J_{\mathrm{d}}=\right.$ $\left.13.8 \mathrm{~Hz}, J_{\mathrm{q}}=7.1 \mathrm{~Hz}, 1 \mathrm{H}\right), 1.83(\mathrm{~m}, 1 \mathrm{H}), 1.96(\mathrm{~s}, 3 \mathrm{H}), 1.95-2.01(\mathrm{~m}, 1 \mathrm{H}), 2.17\left(\mathrm{dq}, J_{\mathrm{d}}=12.5\right.$ $\left.\mathrm{Hz}, J_{\mathrm{q}}=6.2 \mathrm{~Hz}, 1 \mathrm{H}\right), 2.61\left(\mathrm{dq}, J_{\mathrm{d}}=11.0 \mathrm{~Hz}, J_{\mathrm{q}}=6.7 \mathrm{~Hz}, 2 \mathrm{H}\right), 3.03\left(\mathrm{dt}, J_{\mathrm{d}}=10.6 \mathrm{~Hz}, J_{\mathrm{t}}=\right.$ $6.4 \mathrm{~Hz}, 1 \mathrm{H}), 3.23\left(\mathrm{dt}, J_{\mathrm{d}}=11.0 \mathrm{~Hz}, J_{\mathrm{t}}=6.0 \mathrm{~Hz}, 1 \mathrm{H}\right), 3.27(\sim \mathrm{q}, \sim 6.4 \mathrm{~Hz}, 1 \mathrm{H}), 4.12(\sim$ quintet, $6.5 \mathrm{~Hz}, 1 \mathrm{H}), 6.10(\mathrm{bs}, 1 \mathrm{H}) .{ }^{13} \mathrm{C}\{\mathrm{H}\}$ NMR $\left(100 \mathrm{MHz}, \mathrm{CDCl}_{3}, 0.10 \mathrm{M}\right): \delta 23.6,25.5,30.7$, 32.7, 53.3, 55.1, 55.3, 70.8, 170.2. EI-MS (70 eV) $\mathrm{m} / z$ (rel. int.) $\mathrm{M}^{+} 169$ (12.5), 109 (77.5), 108 (100), 83 (97), 82 (52.5), 55 (42.5).

\subsection{Synthesis of ( \pm )-exo-1-acetamidopyrrolizidine (( \pm )-2a)}

Raney Ni (excess) was added to a solution of ( \pm )-1-oximinopyrrolizidine (292 mg, 2.08 mmol) (Christine et al., 2000) in THF (75 mL). The mixture was stirred for $13 \mathrm{~h}$ at rt. Acetic anhydride $(0.196 \mathrm{ml}, 2.08 \mathrm{mmol})$ was added to the mixture, which was stirred at $\mathrm{rt}$ for a further $2 \mathrm{~h}$. It was then filtered through Celite. The filtrate was diluted with saturated aq. $\mathrm{NaHCO}_{3}$ and brine. The aqueous layer was brought to $\mathrm{pH} 12$ with $1 \mathrm{M} \mathrm{NaOH}$, and $\mathrm{CHCl}_{3}$ was added. The phases were allowed to separate for $30 \mathrm{~min}$ at RT. The aqueous layer was extracted with $\mathrm{CHCl}_{3}$ twice, and the combined organic layers were dried over $\mathrm{MgSO}_{4}$, filtered, and concentrated. The residue was purified by flash chromatography (silica gel, $\mathrm{CH}_{2} \mathrm{Cl}_{2} / \mathrm{MeOH} / \mathrm{NH}_{4} \mathrm{OH}, 6: 4: 1.5$, Rf 0.25), affording ( \pm )-2a (29 mg, $0.17 \mathrm{mmol}, 8 \%$ yield) as a white solid, mp $72-74{ }^{\circ} \mathrm{C} .{ }^{1} \mathrm{H}$ NMR $\left(400 \mathrm{MHz}, \mathrm{CDCl}_{3}, 0.17 \mathrm{M}\right): \delta 1.63\left(\mathrm{dq}, J_{\mathrm{d}}=12.4\right.$ $\left.\mathrm{Hz}, J_{\mathrm{q}}=7.0 \mathrm{~Hz}, 1 \mathrm{H}\right), 1.75(\mathrm{~m}, 2 \mathrm{H}), 1.83(\mathrm{~m}, 1 \mathrm{H}), 1.93(\mathrm{~s}, 3 \mathrm{H}), 1.99\left(\mathrm{dq}, J_{\mathrm{d}}=12.9 \mathrm{~Hz}, J_{\mathrm{q}}=\right.$ $7.0 \mathrm{~Hz}, 1 \mathrm{H}), 2.16\left(\mathrm{dq}, J_{\mathrm{d}}=12.6 \mathrm{~Hz}, J_{\mathrm{q}}=6.5 \mathrm{~Hz}, 1 \mathrm{H}\right), 2.62\left(\mathrm{dq}, J_{\mathrm{d}}=11.0 \mathrm{~Hz}, J_{\mathrm{q}}=7.0 \mathrm{~Hz}\right.$, $2 \mathrm{H}), 3.07\left(\mathrm{dt}, J_{\mathrm{d}}=10.8 \mathrm{~Hz}, J_{\mathrm{t}}=6.5 \mathrm{~Hz}, 1 \mathrm{H}\right), 3.29\left(\mathrm{dt}, J_{\mathrm{d}}=10.7 \mathrm{~Hz}, J_{\mathrm{t}}=6.5 \mathrm{~Hz}, 1 \mathrm{H}\right), 3.35$ ( q $, 6.5 \mathrm{~Hz}, 1 \mathrm{H}), 4.12$ ( quintet, $6.5 \mathrm{~Hz}, 1 \mathrm{H}), 6.64$ (bd, $5.9 \mathrm{~Hz}, 1 \mathrm{H}) .{ }^{13} \mathrm{C}\{\mathrm{H}\} \operatorname{NMR}(100$ $\left.\mathrm{MHz}, \mathrm{CDCl}_{3}, 0.17 \mathrm{M}\right): \delta 23.6,25.6,30.8,33.0,53.5,55.4,55.5,71.0,170.1$. IR (ATR): 3272, 1649, 1554. HRMS: $\mathrm{m} / z$ calcd for $\mathrm{C}_{9} \mathrm{H}_{17} \mathrm{~N}_{2} \mathrm{O}(\mathrm{M}+\mathrm{H})$ : 169.1341 ; found: 169.1336 .

\subsection{Genome sequencing}

All genome sequencing and assembly was conducted at the University of Kentucky Advanced Genetic Technologies Center. Genome assemblies of E. festucae E2368, E. amarillans E57, and E. brachyelytri E4804 were described previously (Schardl et al., 2013). The genome of A. hypoxylon B4728 was sequenced on a Roche/454 Titanium pyrosequencer configured for extended reads (average read length $722 \mathrm{nt}$; 32-fold coverage). Assembly was as described previously (Schardl et al., 2013). Assemblies were uploaded to the National Center for Biotechnology Information (NCBI) (Bioproject identifiers: PRJNA42133 for E2368, PRJNA67245 for E4804, and PRJNA67301 for E57, and PRJNA221544 for B4728), 
and are provided with annotations on GBrowse web sites (www.endophyte.uky.edu). Loline gene sequences are deposited in NCBI (GenBank ID: JF830812, JF830813, JF800659, JF800661, JF800660, JF830815, JF830814, JF830816, and KF056806).

\subsection{Analysis of lolO gene}

DNA was purified from endophytes and a fragment of $l o l O$ was amplified by PCR with primer pairs: lolO-F1 and lolO-R2 (Table 2). PCR was performed at $95^{\circ} \mathrm{C}$ for $5 \mathrm{~min}, 35$ cycles of $95{ }^{\circ} \mathrm{C}$ for $30 \mathrm{~s}, 56^{\circ} \mathrm{C}$ for $30 \mathrm{~s}$, and $72{ }^{\circ} \mathrm{C}$ for $1 \mathrm{~min}$. The products were sequenced with the PCR primers.

\subsection{RNA extraction and RT-PCR}

RNA from plant materials were extracted with RNeasy Plant Minikit (Qiagen), removed contaminating DNA using DNA-free ${ }^{\mathrm{TM}}$ kit (Applied Biosystems), and reverse transcribed with high-capacity cDNA Reverse Transcription kit (Applied Biosystems). The resulting cDNA was used as templates to amplify a lolO fragment by PCR with primers lolOs 1 and lolOr. The PCR products were then sequenced with primers lolOs1 and lolO cDNA 3-5.

\subsection{Application of $\mathrm{L}-\left[\mathrm{U}-{ }^{2} \mathrm{H}_{7}\right]$ Pro to plants. A single tiller of El. canadensis plant 4814 , cut}

above the first node, was placed in a test tube with Murashige and Skoog Medium (MS medium) (600 ul) (MP Biomedicals, Solon, OH, USA), pH 7.4 with 4 mM L-[U- $\left.{ }^{2} \mathrm{H}_{7}\right]$ Pro in a $1.7 \mathrm{ml}$ microcentrifuge tube, and maintained at $25^{\circ} \mathrm{C}, 16 \mathrm{~h}$ light, until all the medium was consumed. A total of 10 tillers were used for both $\mathrm{L}-\left[\mathrm{U}_{-}{ }^{2} \mathrm{H}_{7}\right]$ Pro and control (Pro) feeding. The tillers from each experiment were pooled at the end of the feeding period and checked for loline alkaloids following the standard procedure described in section 5.3.

\section{Supplementary Material}

Refer to Web version on PubMed Central for supplementary material.

\section{Acknowledgments}

We thank Sladana Bec for preparation of A. hypoxylon DNA for genome sequencing, Jennifer S. Webb, Emily Gay and Cagney Coomer at the University of Kentucky AGTC facility for genome and PCR product sequencing, Jolanta Jaromczyk for genome assembly, John May at the University of Kentucky ERTL facility for GC-MS analysis, and Johanna E. Takach for sequencing E. amarillans lolO segments. Capable assistance was also provided by Walter Hollin, Julien Nolleau, and Trevor Kellen. This research was supported by USDA-CSREES Grants 2009-11131030 and 2012-6701319384, National Science Foundation Grants EF-0523661 and EPS-0814194, and NIH-NIGMS Grant R01GM086888, and by The Samuel Roberts Noble Foundation, Ardmore, Oklahoma.

\section{References}

An, Z-q; Siegel, MR.; Hollin, W.; Tsai, H-F.; Schmidt, D.; Schardl, CL. Relationships among nonAcremonium sp fungal endophytes in five grass species. Appl Environ Microbiol. 1993; 59:1540 1548. [PubMed: 8517749]

Andrie RM, Martinez JP, Ciuffetti LM. Development of ToxA and ToxB promoter-driven fluorescent protein expression vectors for use in filamentous ascomycetes. Mycologia. 2005; 97:1152-1161. [PubMed: 16596965]

Bacetty A, Snook M, Glenn A, Noe J, Nagabhyru P, Bacon C. Chemotaxis disruption in Pratylenchus scribneri by tall fescue root extracts and alkaloids. J Chem Ecol. 2009; 35:844-850. [PubMed: 19575265]

Blankenship JD, Houseknecht JB, Pal S, Bush LP, Grossman RB, Schardl CL. Biosynthetic precursors of fungal pyrrolizidines, the loline alkaloids. ChemBioChem. 2005; 6:1016-1022. [PubMed: 15861432] 
Blankenship JD, Spiering MJ, Wilkinson HH, Fannin FF, Bush LP, Schardl CL. Production of loline alkaloids by the grass endophyte, Neotyphodium uncinatum, in defined media. Phytochemistry. 2001; 58:395-401. [PubMed: 11557071]

Bultman TL, Bell G, Martin WD. A fungal endophyte mediates reversal of wound-induced resistance and constrains tolerance in a grass. Ecology. 2004; 85:679-685.

Christine C, Ikhiri K, Ahond A, Mourabit AA, Poupat C, Potier P. Synthese des 1-amidopyrrolizidines naturelles, absouline et laburnamine, de derives et d'analogues pyrrolidinoimidazoliques. Tetrahedron. 2000; 56:1837-1850.

Chung KR, Schardl CL. Vegetative compatibility between and within Epichloë species. Mycologia. 1997; 89:558-565. 976.

Dominguez de Maria P, van Gemert RW, Straathof AJ, Hanefeld U. Biosynthesis of ethers: unusual or common natural events? Nat Prod Rep. 2010; 27:370-392. [PubMed: 20179877]

Faulkner JR, Hussaini SR, Blankenship JD, Pal S, Branan BM, Grossman RB, Schardl CL. On the sequence of bond formation in loline alkaloid biosynthesis. ChemBioChem. 2006; 7:1078-1088. [PubMed: 16755627]

Hoveland C. Importance and economic significance of the Acremonium endophytes to performance of animals and grass plants. Agric, Ecosyst Environ. 1993; 44:3-12.

Jensen JG, Popay AJ, Tapper BA. Argentine stem weevil adults are affected by meadow fescue endophyte and its loline alkaloids. N Z Plant Prot. 2009; 62:12-18.

Kutil BL, Greenwald C, Liu G, Spiering MJ, Schardl CL, Wilkinson HH. Comparison of loline alkaloid gene clusters across fungal endophytes: predicting the co-regulatory sequence motifs and the evolutionary history. Fungal Genet Biol. 2007; 44:1002-1010. [PubMed: 17509914]

Latch GCM, Christensen MJ. Artificial infections of grasses with endophytes. Ann Appl Biol. 1985; 107:17-24.

Omacini M, Chaneton EJ, Ghersa CM, Muller CB. Symbiotic fungal endophytes control insect hostparasite interaction webs. Nature. 2001; 409:78-81. [PubMed: 11343116]

Panaccione DG, Johnson RD, Wang J, Young CA, Damrongkool P, Scott B, Schardl CL. Elimination of ergovaline from a grass-Neotyphodium endophyte symbiosis by genetic modification of the endophyte. Proc Natl Acad Sci U S A. 2001; 98:12820-12825. [PubMed: 11592979]

Popay AJ, Tapper BA, Podmore C. Endophyte-infected meadow fescue and loline alkaloids affect Argentine stem weevil larvae. N Z Plant Prot. 2009; 62:19-27.

Riedell WE, Kieckhefer RE, Petroski RJ, Powell RG. Naturally occurring and synthetic loline alkaloid derivatives: insect feeding behavior modification and toxicity. J Entomol Sci. 1991; 26:122-129.

Rudgers JA, Clay K. An invasive plant-fungal mutualism reduces arthropod diversity. Ecol Lett. 2008; 11:831-840. [PubMed: 18479455]

Schardl CL. A global view of metabolites. Chem Biol (Oxford, U K). 2006; 13:5-6.

Schardl CL, Grossman RB, Nagabhyru P, Faulkner JR, Mallik UP. Loline alkaloids: currencies of mutualism. Phytochemistry. 2007; 68:980-996. [PubMed: 17346759]

Schardl CL, Leuchtmann A, Spiering MJ. Symbioses of grasses with seedborne fungal endophytes. Annu Rev Plant Biol. 2004; 55:315-340. [PubMed: 15377223]

Schardl CL, Young CA, Faulkner JR, Florea S, Pan J. Chemotypic diversity of epichloae, fungal symbionts of grasses. Fungal Ecol. 2012; 5:331-344.

Schardl CL, Young CA, Hesse U, Amyotte SG, Andreeva K, Calie PJ, Fleetwood DJ, Haws DC, Moore N, Oeser B, Panaccione DG, Schweri KK, Voisey CR, Farman ML, Jaromczyk JW, Roe BA, O'Sullivan DM, Scott B, Tudzynski P, An Z, Arnaoudova EG, Bullock CT, Charlton ND, Chen L, Cox M, Dinkins RD, Florea S, Glenn AE, Gordon A, Guldener U, Harris DR, Hollin W, Jaromczyk J, Johnson RD, Khan AK, Leistner E, Leuchtmann A, Li C, Liu J, Liu J, Liu M, Mace W, Machado C, Nagabhyru P, Pan J, Schmid J, Sugawara K, Steiner U, Takach JE, Tanaka E, Webb JS, Wilson EV, Wiseman JL, Yoshida R, Zeng Z. Plant-symbiotic fungi as chemical engineers: multi-genome analysis of the Clavicipitaceae reveals dynamics of alkaloid loci. PLoS Genet. 2013; 9:e1003323. [PubMed: 23468653]

Spiering MJ, Faulkner JR, Zhang DX, Machado C, Grossman RB, Schardl CL. Role of the LolP cytochrome P450 monooxygenase in loline alkaloid biosynthesis. Fungal Genet Biol. 2008; 45:1307-1314. [PubMed: 18655839] 
Spiering MJ, Moon CD, Wilkinson HH, Schardl CL. Gene clusters for insecticidal loline alkaloids in the grass-endophytic fungus Neotyphodium uncinatum. Genetics. 2005; 169:1403-1414. [PubMed: 15654104]

Tsai HF, Siegel MR, Schardl CL. Transformation of Acremonium coenophialum, a protective fungal symbiont of the grass Festuca arundinacea. Curr Genet. 1992; 22:399-406. [PubMed: 1423727]

Wilkinson HH, Siegel MR, Blankenship JD, Mallory AC, Bush LP, Schardl CL. Contribution of fungal loline alkaloids to protection from aphids in a grass-endophyte mutualism. Mol PlantMicrobe Interact. 2000; 13:1027-1033. [PubMed: 11043464]

Yates SG, Fenster JC, Bartelt RJ. Assay of tall fescue seed extracts, fractions, and alkaloids using the large milkweed bug. J Agric Food Chem. 1989; 37:354-357.

Zhang DX, Stromberg AJ, Spiering MJ, Schardl CL. Coregulated expression of loline alkaloidbiosynthesis genes in Neotyphodium uncinatum cultures. Fungal Genet Biol. 2009; 46:517-530. [PubMed: 19366635]

Zhang Z, Ren J, Stammers DK, Baldwin JE, Harlos K, Schofield CJ. Structural origins of the selectivity of the trifunctional oxygenase clavaminic acid synthase. Nat Struct Biol. 2000; 7:127133. [PubMed: 10655615] 


\section{Highlights}

- Genomes were sequenced for four fungi with three different loline alkaloid profiles.

- Different loline alkaloid profiles were associated with differences in loline alkaloid biosynthesis gene clusters.

- The LolO non-heme iron oxygenase is required for loline ether bridge formation.

- A novel metabolite, exo-1-acetamidopyrrolizidine, is a likely pathway intermediate in loline alkaloid biosynthesis. 
a

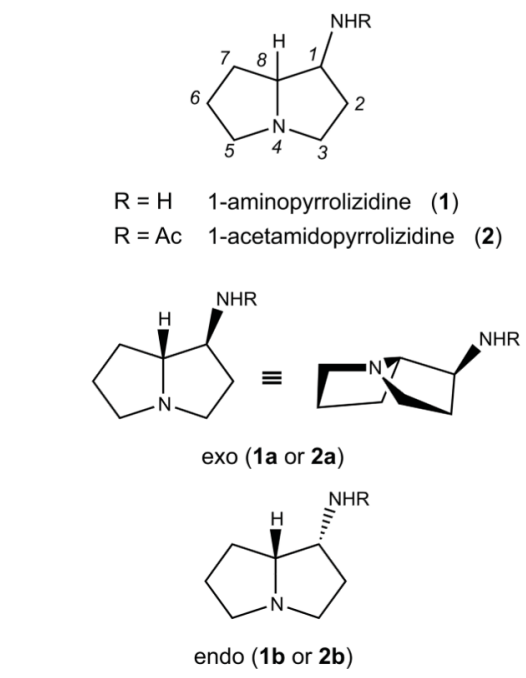

b

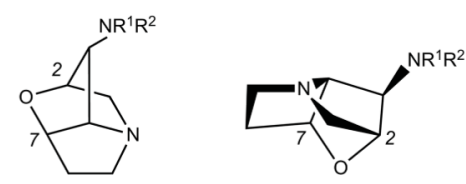

\begin{tabular}{lllll}
$\mathrm{R}^{1}$ & $\mathrm{R}^{2}$ & & & \\
\hline $\mathrm{H}$ & $\mathrm{Me}$ & loline & $(3)$ & \\
$\mathrm{H}$ & $\mathrm{H}$ & norloline $(4)$ & \\
$\mathrm{H}$ & $\mathrm{Ac}$ & $\mathrm{N}$-acetylnorloline & $(5)$ \\
$\mathrm{Me}$ & $\mathrm{Ac}$ & $\mathrm{N}$-acetylloline & $(6)$ \\
$\mathrm{Me}$ & $\mathrm{Me}$ & $\mathrm{N}$-methylloline & $(7)$ \\
$\mathrm{Me}$ & $\mathrm{CHO}$ & $\mathrm{N}$-formylloline & $(8)$
\end{tabular}

Fig. 1.

Perspective illustrations of loline alkaloids. (a) 1-Aminopyrrolizidines. (b) Loline alkaloids, which possess a heterotricyclic core including an ether bridge linking C2 and C7. Substitutions on the nitrogen at $\mathrm{C} 1$ differentiate the lolines. 


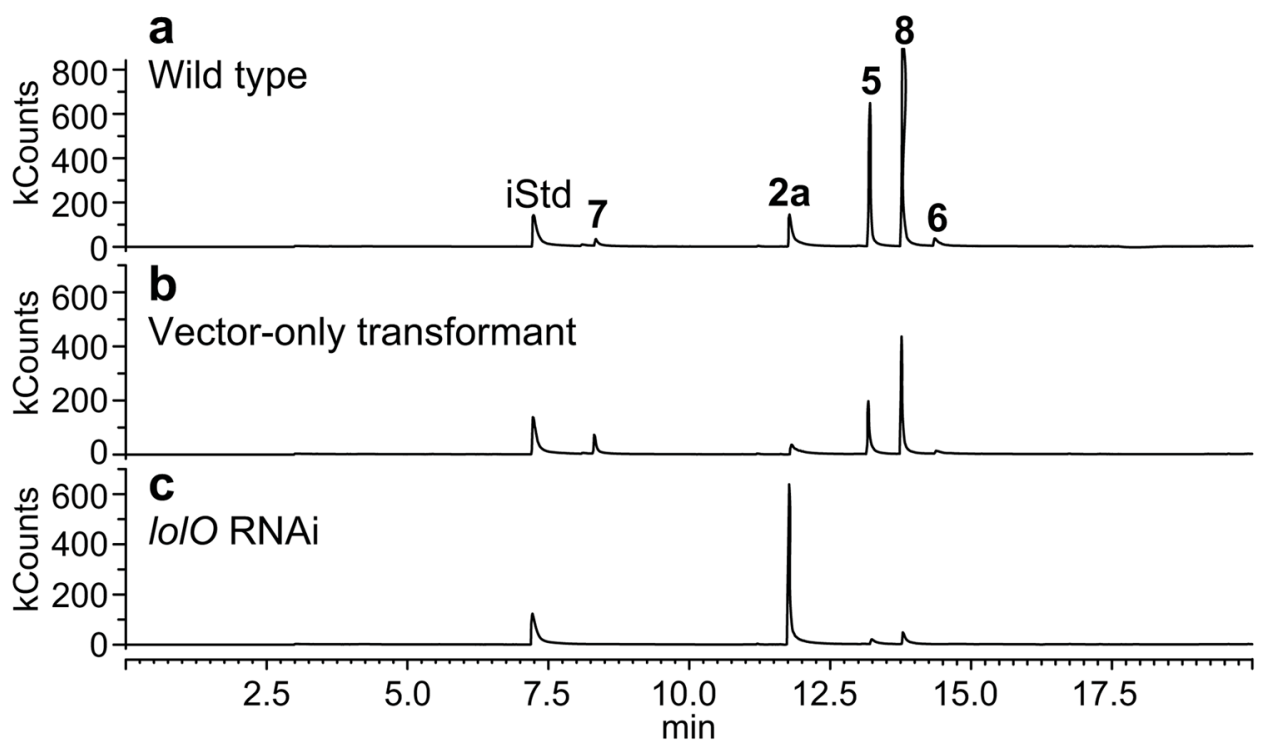

Fig. 2.

GC-MS total ion traces of $N$. uncinatum RNAi transformant and controls showing lolinealkaloid profiles from 25 day-old cultures. Bold numbers indicate the peaks expected for compounds listed in Fig. 1. The internal standard (iStd), quinoline, was used for quantification. (a, b) Chromatograms of products from wild-type N. uncinatum e167 and the vector-only transformant, respectively; (c) chromatogram of products from a lolO RNAi transformant. 


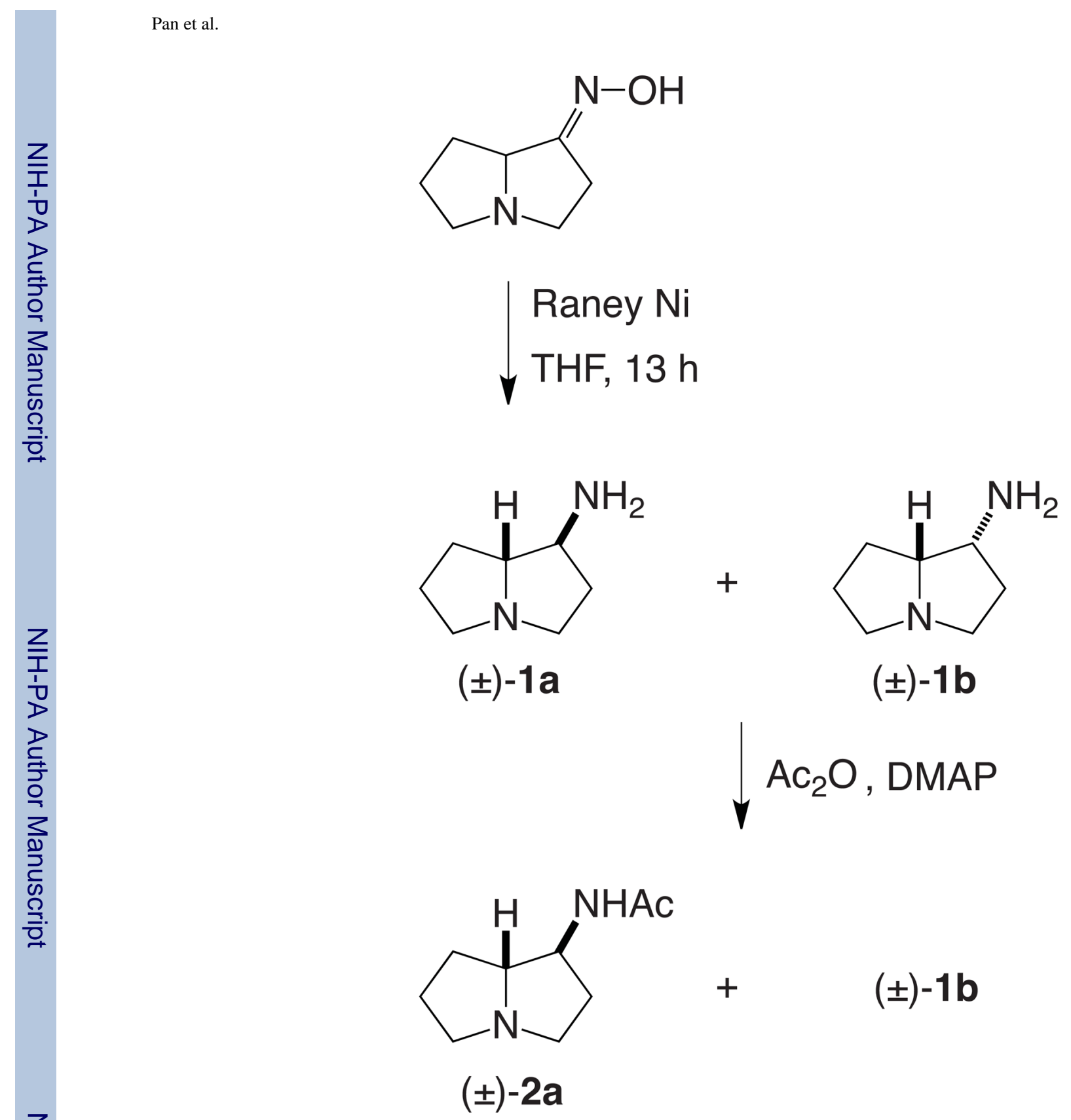

Fig. 3.

Scheme for the synthesis of ( \pm -exo-1-acetamidopyrrolizidine $\mathbf{2 a}$. 


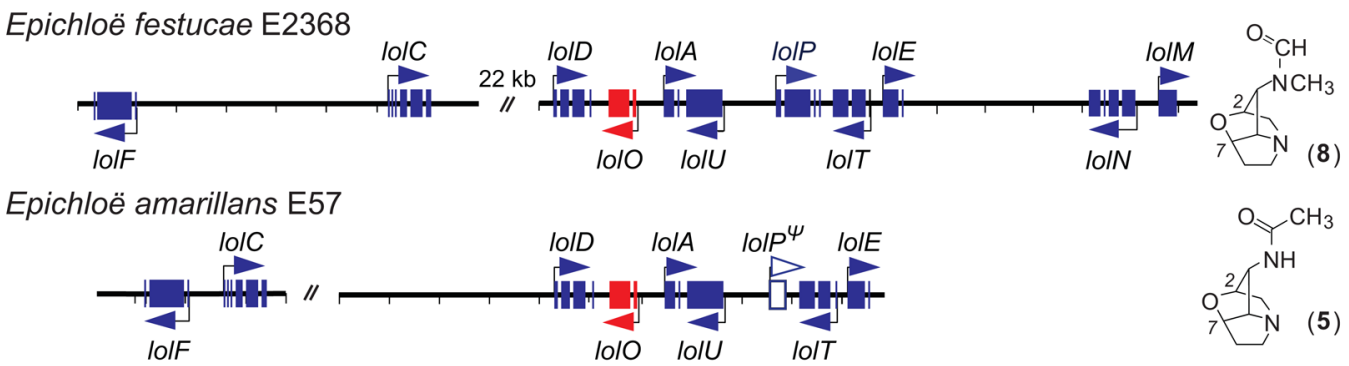

Epichloë brachyelytri E4804
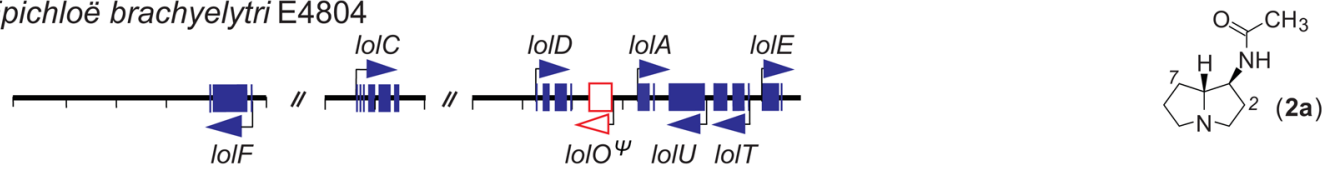

Atkinsonella hypoxylon B4728
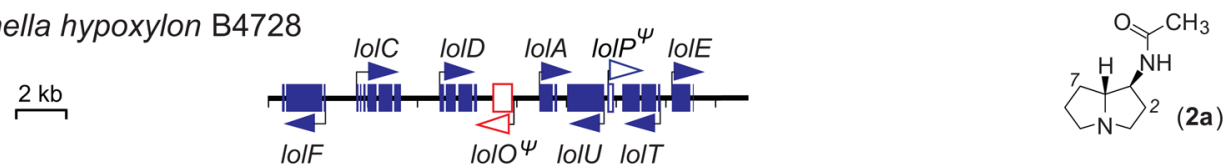

Fig. 4.

Comparison of $L O L$ clusters in four fungal species with different loline alkaloid profiles. The $L O L$ genes are drawn to scale, with filled boxes representing the exons, and gaps between boxes representing introns. Arrows indicate directions of transcription. Empty boxes indicate pseudogenes, and lolO is depicted in red. The chemical structure shown beside each cluster indicates the pathway end product found in each strain. 


\section{Epichloë festucae E2368 \\ Epichloë brachyelytri E4804}

Epichloë amarillans E721, E722, E862

Epichloë canadensis e4815
Epichloë canadensis e4814

Atkinsonella hypoxylon B4728
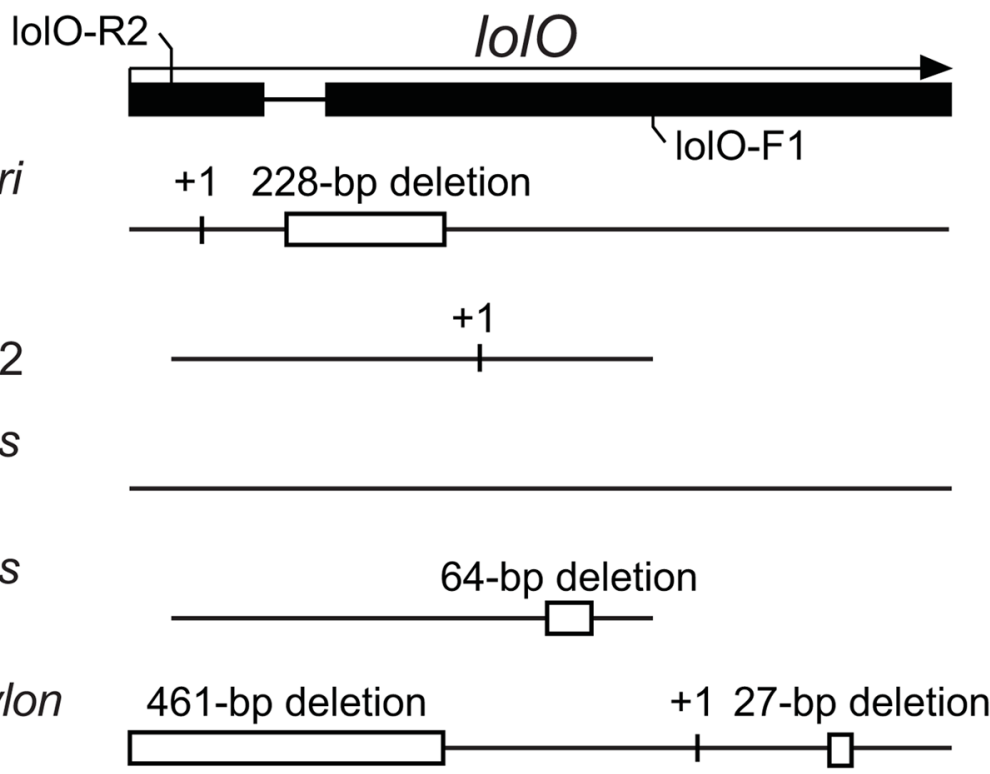

$200 \mathrm{bp}$

Fig. 5.

Schematic representation of $l o l O$ from species that differ in alkaloid profiles. The coding region of lolO from E. festucae E2368 is represented by filled boxes. Binding positions of the primers used for amplification of lolO fragments (for E721, E722, E862 and e4814) are indicated as lolO-F1 and lolO-R2. Sequence coverage of the lolO gene in each strain is indicated by a black bar. Sequence variations are shown as +1 to indicate a frameshift, and open boxes as deletions with the size indicated above each box. The compound listed to the right of each map indicates the pathway end product detected in plants infected with the respective strain. 


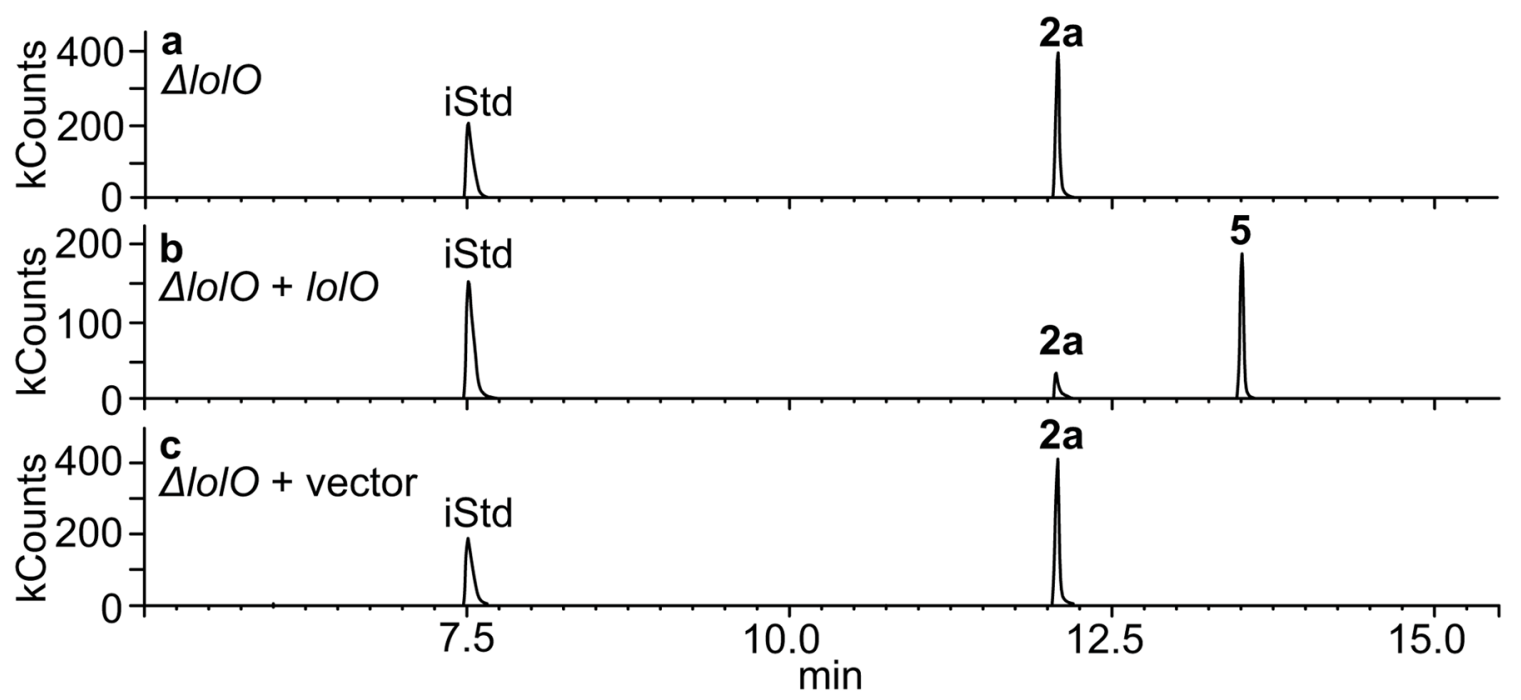

Fig. 6 .

Complementation of E. canadensis e4814 with wild-type lolO. Shown are GC-MS total ion chromatograms of loline alkaloids from the host grass El. canadensis, when symbiotic with: (a) e4814, which has a mutated $l o l O(\Delta l o l O)$; (b) e4814 transformed with a copy of wildtype lolO; (c) e4814 transformed with the vector without lolO. 

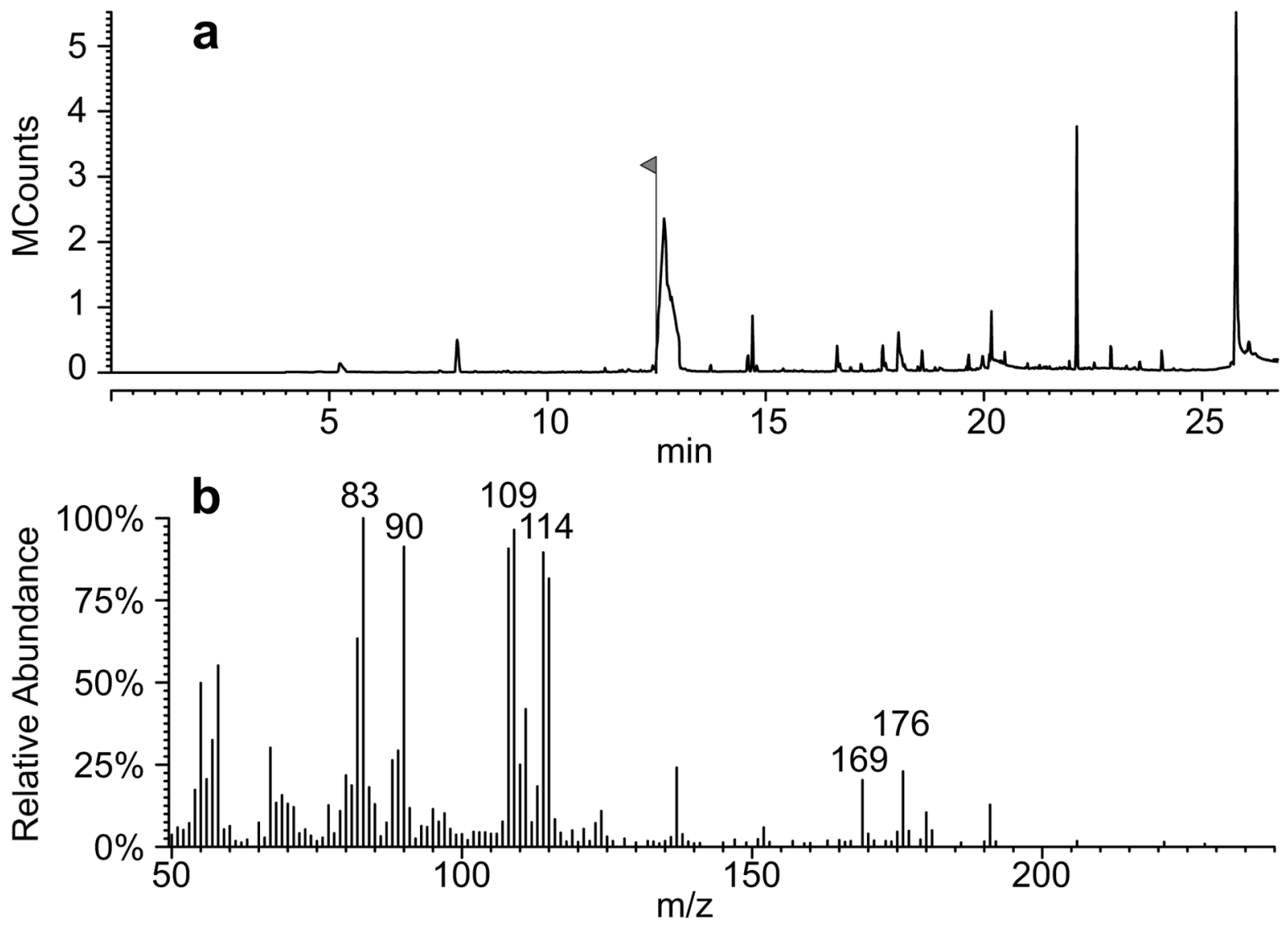

Fig. 7.

Enrichment of deuterated 2a from application of L-[U- $\left.{ }^{2} \mathrm{H}_{7}\right]$ Pro. Shown are mass spectrum (a) and GC-MS total ion chromatogram (b) of compound 2a peak front edge (flagged). 

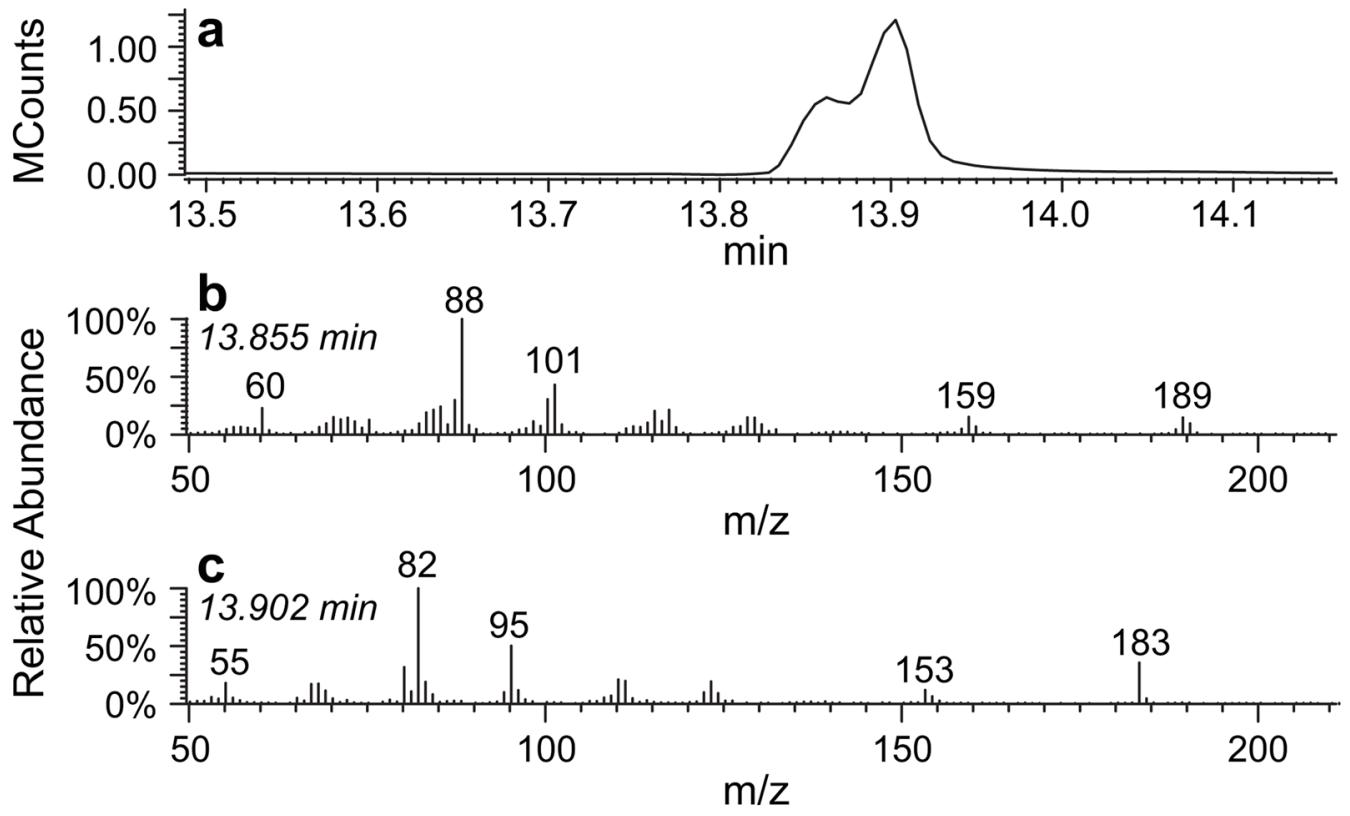

Fig. 8.

GC-MS total ion chromatogram and mass spectrum of $\mathbf{8}$ extracted from L-[U- $\left.{ }^{2} \mathrm{H}_{7}\right]$ Pro feeding. The enrichment of deuterated $\mathbf{8}$ is observed as a shoulder peak separated from its non-deuterated form. (a) Chromatogram of $\mathbf{8}$ extracted from L-[U- $\left.{ }^{2} \mathrm{H}_{7}\right]$ Pro feeding. (b) Mass spectrum of the peak at $13.905 \mathrm{~min}$. (c) Mass spectrum of the peak at $13.855 \mathrm{~min}$. 

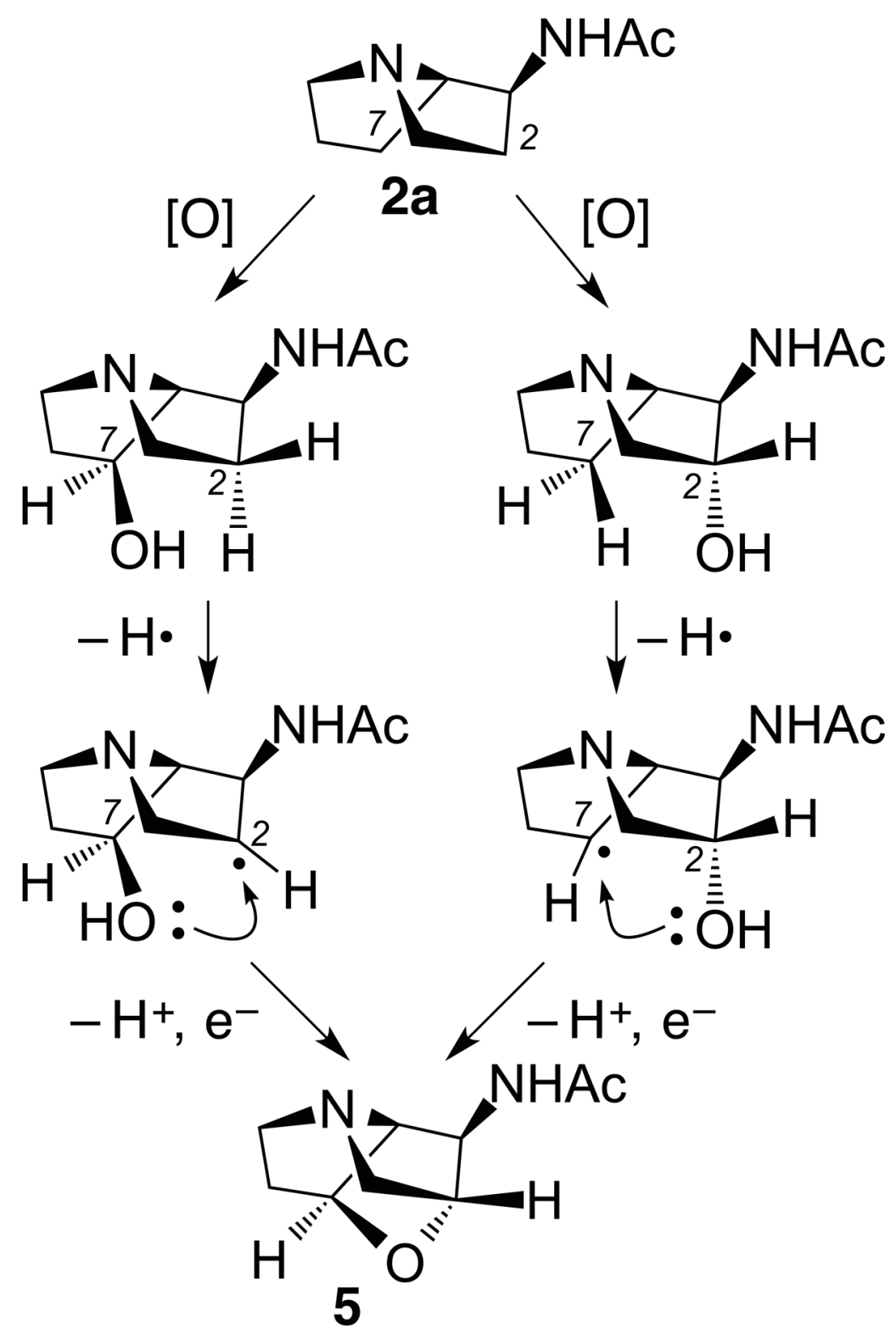

Fig. 9.

A possible pathway for ether bridge formation in loline alkaloid biosynthesis. Other possibilities can also be envisioned. 


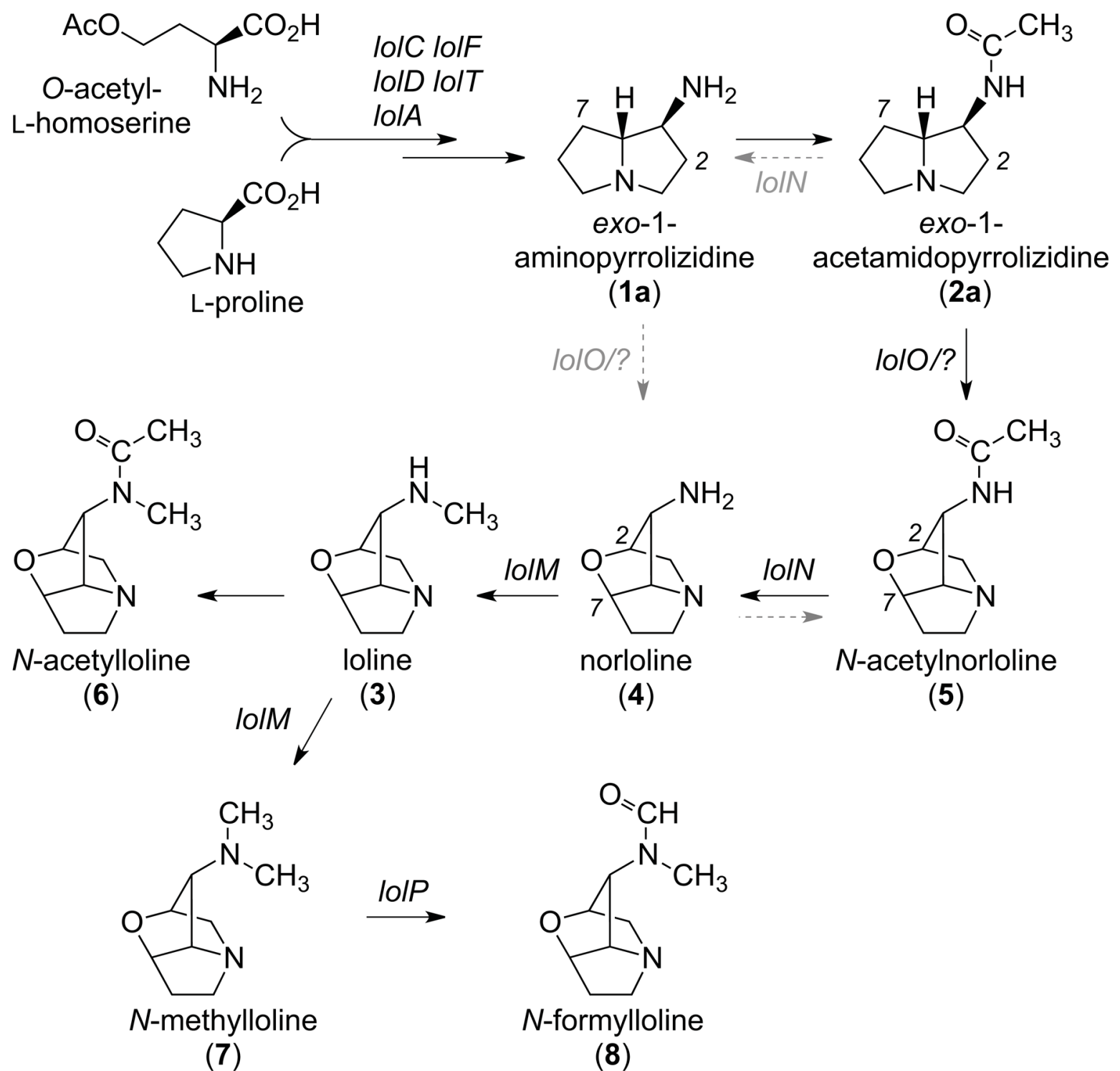

Fig. 10.

Proposed loline alkaloid biosynthetic pathway. Compounds shown are the known precursors, proposed intermediates, and known loline alkaloids produced in symbio. $L O L$ genes with predicted functions are shown with arrows at hypothesized steps. LolO, possibly with another enzyme so far uncharacterized, is proposed to catalyze ether-bridge formation. Gray dashed arrows indicate an alternative hypothesis discussed in the text. 
Table 1

Oligonucleotides used in this study.

\begin{tabular}{|c|c|}
\hline Primer name & Sequence ${ }^{a}$ \\
\hline lolOrnaiF1 & GCGATATCATGACGGTAACAAACAAGCCTG \\
\hline lolOrnaiR1 & CCTCTAGAAATGCAGCCAGGCGAATGCTTACCTCGAGCG \\
\hline lolOrnaiF2 & ATTTCTAGAGGCACACAAGATCAATTAGCGATCC \\
\hline lolOrnaiR2 & ACTACTAGTATGACGGTAACAAACAAGCCTG \\
\hline lolAkoupf & GCGCGGCCGCGAGCTAACCATGCATGGTGT \\
\hline lolAkoupr & GCTCTAGATTCATCGAGCATCGTTAGAATA \\
\hline lolOs1 & ACCTGCCTCTGGCGGTCAAG \\
\hline lolOr & CTTGCGCTCATACTCAAGAGC \\
\hline lolO cDNA 3-5 & CTCCGCCATCTGCCGTTG \\
\hline lolO-F1 & GTGAACTGGCAGTAGTCCGTATG \\
\hline lolO-R2 & AATCCATGCCAGTGTCGGGAATG \\
\hline
\end{tabular}

${ }^{a}$ Underlined segments indicate restriction-endonuclease cleavage sites incoporated in the primers to facilitate cloning. 
Table 2

Origins and source information for fungal strains used in this study.

\begin{tabular}{llll}
\hline Fungus & Isolates & Host & Origin \\
\hline Atkinsonella hypoxylon & $\mathrm{B} 4728$ & Danthonia spicata & Lexington, North Carolina, USA \\
Epichlö̈ amarillans & $\mathrm{E} 57$ & Agrostis hyemalis & Brazoria Co., Texas, USA \\
Epichloë amarillans & $\mathrm{E} 721, \mathrm{E} 722, \mathrm{E} 862$ & Sphenopholis obtusata & Georgia, USA \\
Epichloë brachyelytri & $\mathrm{E} 4804$ & Brachyelytrum erectum & Edmonson Co., Kentucky, USA \\
Epichlö̈ canadensis & $\mathrm{e} 4814^{a}$ & Elymus canadensis & Nuevo León State, Mexico \\
Epichloë canadensis & $\mathrm{e} 4815^{a}$ & Elymus canadensis & Throckmorton Co., Texas, USA \\
Epichloë coenophiala & $\mathrm{e} 19$ & Lolium arundinaceum & Lexington, Kentucky, USA \\
Epichloë festucae & $\mathrm{E} 2368$ & Lolium pratense & Lexington, Kentucky, USA \\
Epichloë uncinata & $\mathrm{e} 167$ & Lolium pratense & Nyon, Switzerland \\
\hline
\end{tabular}

${ }^{a}$ Strains e4815 and e4814 are the equivalent of CWR 5 and CWR 34/36 in Charlton et al. (2012). 